DOI 10.31558/2307-2318.2020.1.10

УДК 330.0

Кліменкова О.В. , старший викладач кафедри менеджменту та поведінкової економіки, Донецького національного університету імені Василя Стуса, Україна

\title{
БІЗНЕС-ОСВІТА ЯК КЛЮЧОВИЙ ФАКТОР ФОРМУВАННЯ КОНКУРЕНТНОГО РИНКУ ПРАЦІ
}

У статті розглянуто взаємозв'язок між попитом та пропозицією на ринку праці та іiі незбалансованістю. Метою дослідження $\epsilon$ вивчення відповідності наявних компетенцій у випускників ВН3 у зіставленні із компетенціями, затребуваними бізнес-середовищем. Предметом дослідження $є$ наявні та очікувані компетенції. Показано розбіжності між наявними компетенціями випускників ВНЗ та затребуваними навичками на ринку праці. Доведено, що система освіти потребує реформи із урахуванням розвитку технологічних та інноваційних процесів. Запропоновано поняття бізнес-освіта як гнучка, адаптивна освіта, яка формує компетенції (навички, знання, вміння та особистісні якості людини) відповідно до сучасних вимог бізнеса і з урахуванням перспектив розвитку економічних процесів, світових та на рівні держави. Визначено напрямки розвитку сучасної освіти із урахуванням потреб підприємств та економіки в цілому. Представлено шляхи досягнення відповідності компетенцій випускників вимогам економіки на думку роботодавців. Рекомендовано продовження діалогу у форматі трьох-стороннього партнерства держава-підприємство-освіта задля вирішення сталого розвитку усіх галузей економіки. Обгрунтовано взаємозв'язок між відтоком робочої сили та незбалансованою кон'юнктурою ринка праці. Представлено бачення зарубіжних та вітчизняних фахівців щодо формування компетенцій бізнесу та компетенцій сучасної молоді, розбіжності та збіги. У якості перспектив подальших досліджень виокремлені поняття бізнес-освіта та бізнес-компетенції. Сформовані потреби вивчення можливостей впровадження програмних підходів бізнес-освіти щодо формування бізнес-компетенцій у випускників ВНЗ. Зроблено висновок про те, що реальний та фінансовий сектори економіки є одними 3 найважливіших замовників на фахівців та впливають на формування попиту i пропозиції ринку праці, формують запит на кваліфікацію випускників ВНЗ. Застосування результатів може буди використано при розробці бізнес орієнтованої системи освіти. Під час написання статті використовувались загальнонаукові методи дослідження: узагальнення, індукція, аналіз, синтез, порівняння, протиставлення.

Ключові слова: бізнес-освіта, компетенції, ринок праці, бізнес-компетенції, університетська освіта, партнерство

Рис. - 2, Табл. - 2, Літ. - 10

\section{Клименкова О.В. \\ БИЗНЕС-ОБРАЗОВАНИЕ КАК КЛЮЧЕВОЙ ФАКТОР ФОРМИРОВАНИЯ КОНКУРЕНТНОГО РЫНКА ТРУДА}

В статье рассмотрена взаимосвязь между спросом и предложением на рынке труда и ее несбалансированностью. Целью исследования является изучение соответствия имеющихся компетенций у выпускников вузов в сопоставлении с компетенциями, востребованными бизнес-средой. Предметом исследования являются имеющиеся и ожидаемые компетенции. Показано разногласия между имеющимися компетенциями выпускников вузов и востребованными навыками на рынке труда. Доказано, что система образования нуждается в реформе с учетом развития технологических и инновационных процессов. Предложено понятие бизнес-образование как гибкое, адаптивное образование, которое формирует компетенции (навыки, знания, умения и личностные 
качества человека) в соответствии с современными требованиями бизнеса и с учетом перспектив развития экономических процессов, мировых и на уровне государства. Определены направления развития современного образования с учетом потребностей предприятий и экономики в целом. Представлены пути достижения соответствия компетенций выпускников требованиям экономики по мнению работодателей. Рекомендуется продолжение диалога в формате трехстороннего партнерства государство-предприятие-образование для решения устойчивого развития всех отраслей экономики. Обоснованна взаимосвязь между оттоком рабочей силы и несбалансированной конъюнктурой рынка труда. Представлены видение зарубежных и отечественных специалистов по формированию компетенций бизнеса и компетенций современной молодежи, разногласия и совпадения. В качестве перспектив дальнейших исследований выделены понятия бизнес-образование и бизнес-компетенции. Сформирована потребность изучения возможностей внедрения программных подходов бизнес образования по формированию бизнес-компетенций у выпускников вузов. Сделан вывод о том, что реальный и финансовый секторы экономики являются одними из важнейших заказчиков на специалистов и влияют на формирование спроса и предложения на рынке труда, формируют запрос на квалификацию выпускников вузов. Применение результатов может быть использовано при разработке бизнес ориентированной системы образования. При написании статьи использовались общенаучные методы исследования: обобщение, индукция, анализ, синтез, сравнение, противопоставление.

Ключевые слова: бизнес-образование, компетенции, рынок труда, бизнескомпетенции, университетское образование, партнерство.

\section{Klimenkova O. \\ BUSINESS EDUCATION AS A KEY FACTOR FOR FORMING A COMPETITIVE LABOR MARKET}

The article researches the relationship between labor market demand and supply and its imbalance. The purpose of the research is to study the correspondence of the existing competencies of university graduates in comparison with the competencies required by the business environment. The subject of the research is the existing and expected competencies. The discrepancies between the existing competences of university graduates and the skills required in the labor market are shown. It has been proved that the education system needs a reform taking into account a technological and innovative processes development. The concept of business education is offered as a flexible, adaptive education that forms competencies (skills, knowledge and personal qualities of a man) in accordance with the modern requirements of business and taking into account the prospects of economic processes, in the world and national level. The directions of development of modern education are considered, taking into account the needs of enterprises and the economy as a whole. The ways of achievement of conformity of graduates' competences with the requirements of economy according to employers are presented. It is recommended to continue the dialogue in the form of a tripartite partnership state-enterprise-education in order to resolve the sustainable development of all sectors of the economy. The relationship between labor outflow and unbalanced labor market conditions is justified. The vision of foreign and domestic experts on formation of business competencies and competencies of modern youth, differences and coincidences, is presented. The concepts of business education and business competence are outlined as prospects for further research. The needs of studying possibilities of implementing business education programmatic approaches to the formation of business competencies among university 
graduates have been formed. It is concluded that the real and financial sectors of the economy are one of the most important customers for specialists and they have influence on formation of labor market demand and supply, form the request for qualification of university graduates. The application of the results can be used in development of a business oriented education system. During the writing of the article, general scientific research methods were used: generalization, induction, analysis, synthesis, comparison, opposition.

Keywords: business education, competencies, labor market, business competencies, university education, partnership

Постановка проблеми у загальному вигляді. Трансформаційні процеси, які відбуваються сьогодні в Україні охоплюють всі сектори економіки і торкаються також перебудови системи освіти і реформування ринку праці. Серед основних положень реформ освіти і ринку праці є окремі точкові норми які спрямовані на задоволення вимог споживачів освітніх послуг 3 одного боку, та на забезпечення потреб роботодавців в якісній кваліфікованій робочий силі, з іншого боку. Також зазначені реформи мають за мету зупинити відтік молоді за кордон і забезпечити їх конкурентною працею і оплатою у межах країни. Але ми спостерігаєм, що молодь випускники ВНЗ, стикаються з проблемою при працевлаштуванні, а саме, із відмовою за причин відсутності практичного досвіду, або за причин недостатньої кваліфікації. Представники ж бізнесу подають чіткі меседжі про невідповідність навичок і знань випускників сучасним вимогам бізнесу і звертаються до альтернативної освіти бізнес-шкіл, тренінгових та консалтингових компаній задля перенавчання персоналу і формування відповідних компетенцій.

Аналіз досліджень і публікацій останніх років показав, що головна увага приділяється питанням удосконалення підготовки кваліфікованих фахівців, регулюванню ринку праці та зайнятості населення; у дослідженнях розглядаються проблеми відтворення людського капіталу, проблеми управління людським капіталом, питання відтворення i руху людського капіталу; підіймаються питання щодо ефективності взаємодії між державою, реальним сектором економіки та навчальними закладами. Вагомий внесок в дослідження актуальних проблем внесли вітчизняні вчені О. І. Амоша, В. П. Антонюк, С. С. Аптекар, С. І. Бандур, Д. П. Богиня, О. А. Грішнова, А .М. Колот, Є. М. Лібанова, Ю.М. Маршавін, О.Ф. Новікова, Л.В. Шаульська. Автори розглядають досить важливі аспекти, та водночас необхідно зауважити, що доцільно і надалі проводити дослідження в напрямку реформування сучасної освіти і формуванні конкурентоспроможних навичок і вмінь молоді, як перспективи розвитку економіки держави в цілому.

Виділення невирішених раніше частин загальної проблеми. Сучасні дослідження науковців присвячені розвитку та формуванню людського капіталу, підготовці кваліфікованих фахівців, підвищенню конкурентоспроможності випускників ВНЗ, диспропорціям між попитом і пропозиціями на ринку праці. Сучасні ринкові трансформації супроводжуються загостренням протиріч між якісними характеристиками наявних компетенцій у випускників та реальними потребами технологічних, інноваційних процесів і бізнесу, i тому потребують швидкого реагування усіх стейкхолдерів щодо розбудови системи партнерства між державою, бізнесом та вищими навчальними закладами.

Постановка завдання. Метою дослідження $є$ вивчення відповідності наявних компетенцій у випускників ВНЗ у зіставленні із компетенціями, які затребувані у сучасному бізнес-середовищі. До завдань дослідження варто віднести систематизацію 
таких складових як: ринок праці, компетенції, бізнес-компетенції, сучасна освіта, бізнесосвіта i вплив перелічених чинників на задоволеність роботодавців i конкурентоспроможність молоді.

Виклад основного матеріалу дослідження. Сучасний ринок праці знаходиться на етапі трансформації i потребує всебічного розгляду існуючих процесів i взаємозв'язків між суб'єктами, об'єктами та регуляторами ринку. Сучасні виклики та загрози ринку праці потребують зміни в структурі попиту та пропозиції, ставлять нові завдання до процесів його формування та регулювання. Однією 3 таких проблем $\epsilon$ недостатній рівень задоволеності потреби роботодавців в кадрах, що здебільшого обумовлено неефективністю системи професійного самовизначення молоді, відсутністю систематизованої інформації щодо актуальних на ринку праці професій, низьким рівнем взаємодії між роботодавцями та освітньою сферою, недосконалістю існуючої системи освіти, зниженням якості підготовки студентів за рахунок зростання кількості приватних вищих навчальних закладів тощо. Все це загострює проблеми надлишку робочої сили з вищою освітою, при низькій якості підготовки молодих фахівців, зменшує віддачу від інвестицій у людський капітал і стримує розвиток економіки. Ключовим критичним моментом в цьому процесі залишається працевлаштування молоді, як однієї, з одного боку, найбільш перспективної частини населення, а 3 іншого найбільш вразливої. Вирішення проблеми молодіжного безробіття є можливим лише за умов активізації співпраці між закладами освіти та роботодавцями. Також, однією 3 причин незбалансованості ринку праці $є$ відсутнісь бажання молоді здобувати професії, що користуються попитом серед роботодавців. Сучасна молодь при обранні професій в більшості випадків не орієнтується, майже, на наявну поточну затребуваність отриманого фаху, зосереджуючи свою увагу на можливість фінансового благополуччя після отримання робочого місця. При чому, в зв'язку з низьким рівнем інформованості щодо ринку праці, молодь вважає, що та чи інша професії принесуть їм гідну оплату праці. Існуючі проблеми на ринку праці поглиблює відсутність чіткої інформації та уявлень студентів і випускників щодо ступеня важливості різноманітних особистісних та професійних характеристик, необхідних в трудовій діяльності. Це не дає змогу індивіду сформувати вірну стратегію самоосвіти та самовдосконалення задля підвищення рівня своєї конкурентоспроможності на ринку праці. Відсутність у студентства уявлень відносно свого майбутнього $\epsilon$ також доволі застарілою проблемою, що пояснюється вкрай штучними умовами навчання, та не дозволяє сформувати цілісне уявлення про можливості, які існують у зовнішньому середовищі. Включені у межах навчального процесу виробничі практики, носять переважно формальний характер та не дають можливості майбутнім фахівцям апробувати власні здібності, що нівелює навіть мінімальні зусилля щодо продуктивного контакту з майбутнім місцем роботи.

Все це актуалізує та висвітлює у новому ракурсі ідею практико-орієнтованого навчання, здатного створити умови щодо нарощування адаптаційного потенціалу майбутніх випускників, яка є вкрай очікуваною та затребуваною. Маємо ситуацію, коли зусиль та часу університет витрачає забагато, але він формує у межах власних навчальних процесів компетентісний профіль, який не співпадає 3 вимогами роботодавців, це по-перше. По-друге, теоретичний та, в більшості випадків, застарілий матеріал, що не відповідає емпіричним реаліям господарювання, не сприяє формуванню у майбутнього випускника високого адаптаційного потенціалу до умов зовнішнього середовища, що визначається зростаючою складністю та невизначеністю. Мова йдеться про розбіжності між очікуваннями роботодавця та наявними компетенціями випускників. Формуванню компетенцій, які б відповідали сучасним потребам бізнеса, 
наразі приділяється багато уваги вітчизняними, міжнародними експертами та стейкхолдерами.

Розглянемо на прикладах затребувані компетенції у бізнесі. Так, ще у 2015 році на Всесвітньому економічному форумі (World Economic Forum, ВЕФ) у Давосі підіймалося питання ключових компетенцій, важливих для розвитку бізнеса у майбутньому, що означає потребу у наявності цих самих компетенцій у керівників середньої та топової ланки i, відповідно, у випускників ВНЗ.

В таблиці №1 представлені ключові компетенції, які будуть затребуваними на думку міжнародних експертів у 2020 року в порівнянні із компетенціями, актуальними у 2015 році.

Наведені компетенції 2020 року показують про розбіжності існуючих програм підготовки студентів ВНЗ та затребуваних вже сьогодні в бізнесі. Наприклад, компетенції «Рішення комплексних проблем», «Креативність», «Узгодження дії 3 іншими людьми» не включені в освітні програми університетів.

Ключові компетенції за версісю експертів ВЕФ

Таблиця 1

\begin{tabular}{|c|l|l|}
\hline № & \multicolumn{1}{|c|}{2015 рок } & \multicolumn{1}{|c|}{2020 рок } \\
\hline 1 & Рішення комплексних проблем & Рішення комплексних проблем \\
\hline 2 & Узгоджені дії з іншими людьми & Критичне мислення \\
\hline 3 & Управління людьми & Креативність \\
\hline 4 & Критичне мислення & Управління людьми \\
\hline 5 & Ведення переговорів & Узгоджені дії з іншими людьми \\
\hline 6 & Контроль якості & Емоційний інтелект \\
\hline 7 & Оріснтація на надання послуг & Експертна оцінка і прийняття рішень \\
\hline 8 & Експертна оцінка і прийняття рішень & Орієнтація на надання послуг \\
\hline 9 & Активне слухання & Ведення переговорів \\
\hline 10 & Креативність & Гнучкість мислення \\
\hline
\end{tabular}

Розглянемо приклад бізнес-компетенцій, наведених групою вітчизняних експертів у дослідженні «Оцінка економічного потенціалу університетів Донбасу: проблеми підготовки кадрів і безробіття», проведеному у 2018 році. Проведене дослідження дало можливість визначити основні наявні проблеми у сфері підготовки кадрів в університетах, оцінити рівень задоволеності роботодавців та студентів якістю набутих знань, вмінь та навичок, а також визначити найбільш критичні компетенції, які $\epsilon$ найменш розвиненими у випускників.

Так, досліджуючи відповідність наявних компетенцій випускників потребам роботодавців, експерти запропонували «Матрицю збалансованості вимог роботодавців до випускників та наявних характеристик за компетенціями» (Таб. 2, Рис. 1)

За результатами дослідження відповідності рівня вмінь і знань сучасних молодих фахівців явленням роботодавців щодо «ідеального» випускника, визначено, що за двадцятьма двома визначеними критеріями якості вони характеризуються негативним значенням коефіцієнту якості, що коливається в межах від -0,41 до -1,23. 
Таблиця 2

\section{Матриця збалансованості вимог роботодавців до випускників та наявних характеристик за компетенціями}

1- Загальна теоретична підготовка за профілем

2 - Вміння виконувати основні професійні функції за профілем

3 - Вміння застосовувати набуті навички

4 - Знання іноземних мов

5- Вміння працювати на комп'ютері

6 - Знання спеціалізованих прикладних програм необхідних для здійснення професійної діяльності

7 - Володіння навичками

8 - Знання про основні технологічні процеси професійної діяльності

9 - Обізнаність із законодавчо-нормативною базою у сфері професійної діяльності

10 - Володіння суміжними знаннями та навичками (не за основним напрямом професійної діяльності)

11 - Володіння навичками міжособистісного спілкування (комунікабельність)

12 - Вміння працювати в команді

13 - Вміння організувати власну діяльність (визначати мету та завдання власної діяльності, порядку виконання завдань, тощо) теоретичні знання у професійній діяльності
14 - Вміння враховувати корпоративні інтереси в трудовій діяльності 15 - Вміння шукати та використовувати нову інформацію

16 - Лояльність до керівництва та співробітників

17 - Здатність справлятися з новими та непередбачуваними ситуаціями збирання, обробки, аналізу, узагальнення інформації та презентації результатів 18 - Здатність адекватно оцінювати ситуацію, розпізнавати й враховувати більшість зовнішніх та внутрішніх чинників

19 - Вміння проявляти ініціативу у професійній діяльності

20 - Творчий потенціал (здатність до інновацій та новаторства)

21 - Дисциплінованість

22 - Лідерські якості

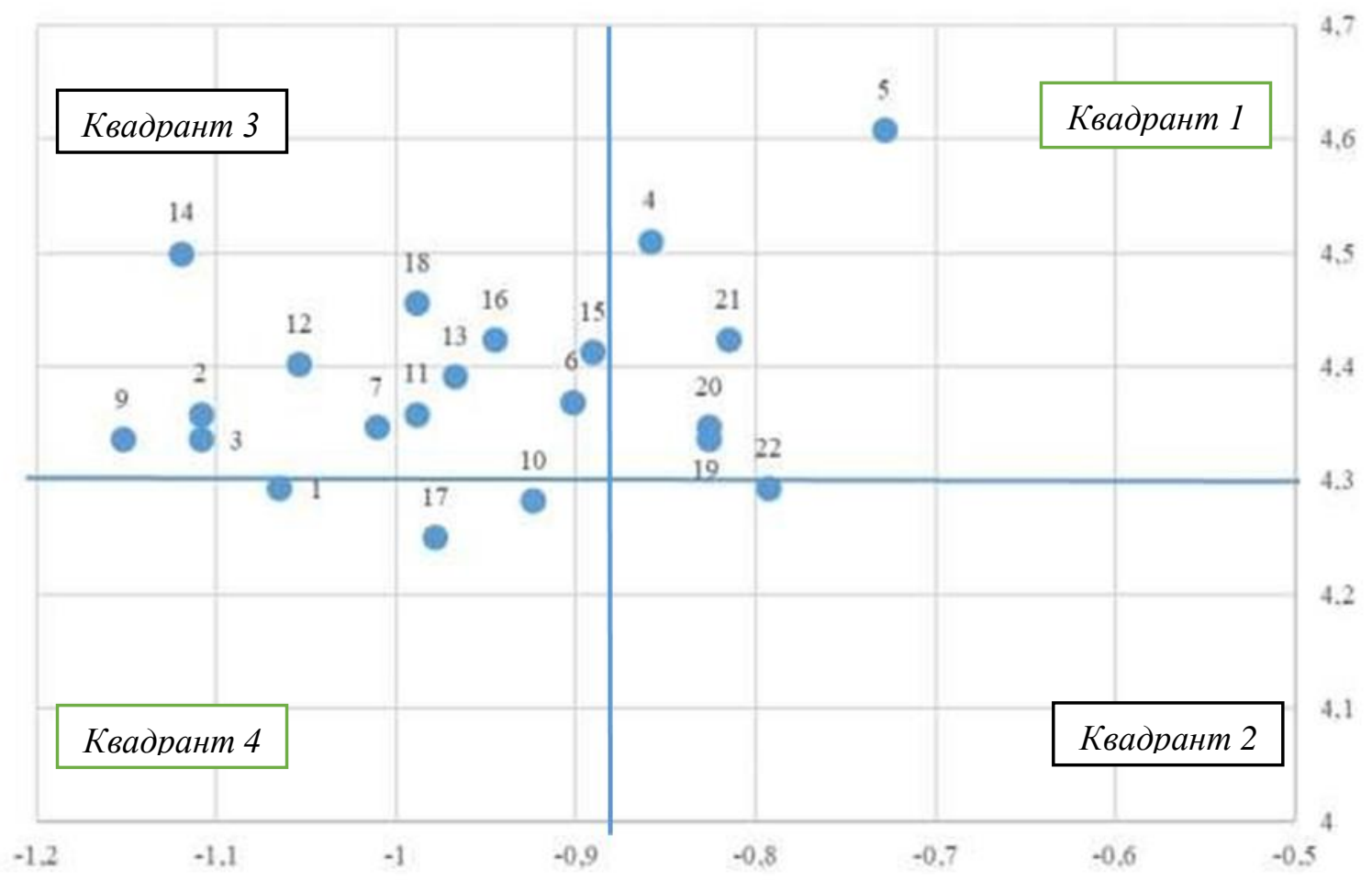

\section{Рисунок 1 - Матриця збалансованості вимог роботодавців до випускників та наявних характеристик за компетенціями}


Тобто спостерігається досить високий ступінь незадоволеності вимог роботодавців молодими фахівцями. Проте більш показовим для аналізу якості та визначення існуючих проблем є співвідношення коефіцієнту якості критерію та ступенем важливості цього критерію у професійній діяльності фахівця. Графічно це співвідношення наведено на рисунку 1.

До Квадранту 1, що містить критерії, які мають високий ступінь важливості та порівняно високий з іншими рівень їх якості і через це маються за найблагополучніші в поточному стані, увійшли:

вміння працювати на комп'ютері;

дисциплінованість - посідає сьоме місце в рейтингу важливості критеріїв;

творчий потенціал посідає п'ятнадцяте місце серед ключових характеристик сучасного молодого фахівця і має досить високий рівень важливості;

вміння проявляти ініціативу в професійній діяльності має майже граничне значення переходу на межі квадранту один два та три, входить до ризикової та критичної зони, що потребує певних втручань з боку системи освіти щодо покращення його якісного рівня.

Загалом усі критерії, що увійшли до квадранту 1, є позитивними в плані задоволення потреб роботодавців, однак існують деякі резерви їх розвитку, адже ступінь відхилення якості випускників від еталону є доволі високим. Крім того, є критерії що опинились у проблемній перехідній зоні, що обумовлює необхідність звернути саме на них більшу увагу при формуванні пропозицій щодо підвищення конкурентоспроможності молоді.

До Квадранту 2, що містить в собі критерії, які характеризуються низьким значенням показника важливості та низьким коефіцієнтом якості, тобто є не ключовими та їх поточний рівень майже задовольняє потреби роботодавців, належать: лідерські якості, рівень важливості яких є найменшими серед усіх показників та складає 4,29 бали. При цьому індекс задоволеності залишається достатньо високим $Q_{i}=-0,79$. Це говорить про те, що більшість роботодавців не бачать в молоді лідерів та розглядають цей персонал лише у форматі професійних виконавців.

Найпроблемнішим та поширеним за кількістю критеріїв, що опинились в ньому, при оцінці рівня конкурентоспроможності випускників, є Квадрант 3: до нього увійшло тринадцять 3 двадцяти двох компетенцій, яких було виокремлено для аналізу. Саме ці компетентісні характеристики потребують якнайшвидшого покращення, оскільки вони $\epsilon$ на думку роботодавців, ключовими в трудовій діяльності та мають сьогодні найнижчі значення коефіцієнта якості:

знання іноземної мови, знаходиться майже на перетині першого та третього Квадрантів, це говорить з одного боку про високий рівень важливості даного критерію та майже задовільнений характер якості навички. Поряд з тим, слід зазначити, що саме цей критерій був обраний одним 3 найбільших переваг сучасної молодої. Значення критерію важливості дорівнює - 4,51 бали, що займає друге місце серед загального рейтингу та шосте місце за коефіцієнтом якості $\left(Q_{i}=-0,86\right)$;

знання спеціалізованих програм для використання у професійній діяльності характеризується середнім ступенем важливості (4,37 балів) та має значення коефіцієнту якості $Q_{i}=-0,9$, що є дискусійним з точки зору порівняння його критичності з показником знання ПК (який займає лідируючи позиції за рівнем задоволеності), це говорить про те, що актуальним $є$ поглиблення наявних знань спеціалізованим навчанням на фоні надання загальних знань комп’ютерних технологій; 
обізнаність із законодавчо-нормативною базою організації професійної діяльності: знання основ трудового, адміністративного та господарського права - все це $\epsilon$ необхідною та об'єктивною вимогою сучасності. Враховуючи це, роботодавці в ході опитування визнали досить важливим і бажаним факт наявності правових знань у випускників (важливість 4,34). Існуючі сьогодні освітні програми містять в собі правові дисципліни, що дають базові знання щодо організації відповідної до законодавства трудової та господарської діяльності, однак опитування показали, що якість цих знань $\epsilon$ дуже низькою (найнижчий показник якості серед усіх компонентів) $\left(Q_{i}=-1,15\right)$ та не відповідає сучасним вимогам;

вміння організувати свою діяльність як складову колективної діяльності: одна 3 ключових соціально-особистісних компетенцій, що формується на етапі середньої та професійної освіти, дає змогу забезпечувати ефективну командну колективну роботу та дає змогу функціонувати підприємству як цілісній структурі. Однак існуюча система освіти не в змозі забезпечити достатній рівень цієї компетенції, це підтверджується низьким значення коефіцієнту якості важливості 4,39 з 5;

показник вміння враховувати корпоративні інтереси у трудовій діяльності посідає третє місце серед двадцяти двох критеріїв за ступенем важливості для роботодавців із значенням показника важливості 4,5, що є цілком об'єктивним, адже керівництво підприємства бажає, щоб співробітники були відданими своїй компанії та працювали, враховуючи іiі стратегічні цілі та завдання. Але за визначенням роботодавців ступінь формування цієї компетенції у випускників є занадто низьким, незадоволеність ії якістю складає $(-1,12$ - двадцяте місце у рейтингу задоволеності);

наявність практичних навичок: $є$ однією 3 конкурентних переваг фахівців, які мають достатній досвід роботи за фахом, що дає змогу без додаткового навчання i перенавчання взятися до трудової діяльності, тому роботодавці вбачають наявність цього критерію дуже важливим (показник важливості 4,36) та бажають, щоб рівень його представленості у молодих фахівців був доволі високим. Однак сучасна система не в змозі забезпечити достатній рівень розвиненості цієї навички через специфічність та більш теоретичну спрямованість української системи освіти, тому коефіцієнт якості за цим критерієм є дуже низьким $(-1,08)$ та входить у четвірку показників 3 найгіршою якістю;

загальна теоретична підготовка за профілем: іï належний рівень є головним завданням системи освіти. Але сьогодні вона не в змозі виконувати його на належному рівні. Коефіцієнт якості теоретичної підготовки випускників дорівнює $(-1,06)$ i перебуває на вісімнадцятому місці з двадцяти двох;

вміння працювати в команді посідає шосте місце серед характеристик, рівень розвиненості яких не відповідає вимогам роботодавців (коефіцієнт якості $Q_{i}=-1,05$ ). Крім того, для нього є характерною і висока важливість (4,4 бали), що підкреслює критичність стану даного показника та вимагає швидких дій щодо його покращення;

володіння навичками збирання обробки, аналізу та презентації інформації $€$ компетенцією, що характеризує професійний рівень фахівця 3 точки зору оцінки можливостей використання його знань. Ця компетенція отримала середній показник важливості та середній показник якості, що не є критичним, але все одно відносить їх до групи критичних та потребуючих доопрацювання;

комунікабельність - не є позитивною рисою сучасної молоді, що ускладнює процеси побудови взаємодії при організації виробничого процесу, як між керівником та підлеглим, так і між колегами, це зменшує ефективність загальної діяльності та 
негативно впливає на процес формування та виконання завдань. Оцінка якості цього показника знаходиться на рівні «-0,99», а важливості 4,36 балів з 5.

До 4 Квадранту показників, що мають найменший рівень важливості, але мають критичні показники якості роботодавцями було віднесено:

здатність справлятися з новими та непередбачуваними ситуаціями, низький рівень важливості яких (4,25 балів) говорить про сталість виробничих процесів та завдань, що можуть виникати в процесі професійної діяльності молодого фахівця, а низький рівень якості - про відсутність можливості розвинути ці навички в рамках системи освіти та життя $\left(Q_{i}=-0,98\right)$;

володіння суміжними знаннями та навичками, посідає двадцять перше місце за рівнем важливості - 4,28 балів та дев'яте місце за рівнем якості $\left(Q_{i}=-0,92\right)$.

Проведений аналіз виявив високий рівень незадовільності роботодавців рівнем якісних характеристик випускників. Молоді фахівці не в змозі вільно конкурувати на ринку праці за достойні робочі місця, тому не можуть повною мірою замінити вивільнену робочу силу. Основними причинами ситуації, що склалась, є критичні значення якості практичної підготовки випускників та комплексу соціально-особистісних компетенцій, що говорить про необхідність посилення саме цих складових освітньої діяльності. Втім, роботодавці бачать можливості збільшення рівня компетентності випускників, за допомогою наступних шляхів: більш ніж $63 \%$ респондентів зазначають на ефективності впровадження практики використання викладачів 3 практичним досвідом; майже 40\% зазначають на необхідності розширення методів практичного навчання, в т.ч. безпосередньо на виробництві; четверта частина наголошують на необхідності впровадження практики прогнозування потреб ринку праці у кваліфікованій робочій силі не тільки в кількісному, а й в якісному виразі (рисунок 2).



$0,00 \% \quad 10,00 \% 20,00 \%$ \% $30,00 \%, 40,00 \% 650,00 \% 60,00 \% 70,00 \%$

Рисунок 2 - Шляхи досягнення відповідності компетенцій випускників вимогам економіки (на думку роботодавців) 
Занизькі оцінки якості випускників ще раз підкреслюють факт низького рівня конкурентоспроможності сучасної молоді з вищою освітою на ринку праці. Основною причиною ситуації, що склалась, є недосконалість існуючої системи підготовки кадрів в країні, це підтверджують низькі оцінки рівня теоретичних знань та практичних навичок випускників.

Організація чіткої співпраці між навчальними закладами та бізнесом, на сьогодні бачиться одним 3 ключових інструментів подолання існуючого розриву в якості підготовки робочої сили та вимог роботодавців, а також подолання безробіття серед молодшого покоління. Незбалансованість між попитом і пропозицією кадрів на ринку праці в певній мірі пов'язана з відсутністю ефективної взаємодії між діяльністю 3ВО та потребами підприємств. Саме спільнота зацікавлених осіб, чиї інтереси перехрещуються, зможуть забезпечити формування релевантного образу досконалого освітянського процесу та його результатів, що відбиваються на адекватній структурі компетентнісного профілю випускників. Симбіоз університетів, роботодавців, регіональних органів влади $є$ необхідною складовою процесу гармонізації виконуваних ВНЗ функцій з базовими потребами соціально-економічного розвитку країни в цілому. Тому рекомендовано продовжувати діалог в форматі трьох-стороннього партнерства держава-бізнес-університет. На сьогодні бізнес є одним з найважливіших і реальних замовників на фахівців. В умовах нестачі кваліфікованих кадрів, в тому числі, в вузькопрофільних областях знань, бізнес починає активно заповнювати дефіцит знань «власними зусиллями» або через нові форми додаткової освіти - друга вища освіта, курси підвищення кваліфікації, семінари, бізнес-школи, бізнес-освіта, тощо. Ці освітні форми набагато швидше орієнтуються на потреби сучасного суспільства, на появу нових галузей і виробництв, ніж традиційна п'ятирічна освіта.

Висновки і перспективи подальших розробок. На основі вищевикладеного, можемо зробити наступні висновки: необхідно переорієнтувати розвиток вищої освіти, створювати механізми узгодження пропозиції освітніх послуг і потреб ринку праці, займатися стратегічним плануванням розвитку даної сфери; підвищувати рівень розвитку компетенцій, вмінь та навичок сучасного молодого фахівця, з урахуванням перспектив розвитку бізнесу та в тісній взаємодії з ними; приділяти більше уваги Центрам розвитку кар'єри при університетах, а саме розширити функції й долучати до співпраці 3 підприємствами в напрямку проходження практики 3 подальшим працевлаштуванням; вивчати практику бізнес-освіти, яка більш орієнтована на формування бізнес-компетенцій і $є$ більш гнучкою в порівняні із ВНЗ. Автором запропоновано ввести поняття «Бізнес-освіта». «Бізнес-освіта - це гнучка, адаптивна освіта, яка формує компетенції (навички, знання, вміння та особистісні якості людини) відповідно до сучасних вимог бізнеса і з урахуванням перспектив розвитку економічних процесів, світових та на рівні держави» (авторська розробка). В статті було представлено бачення зарубіжних та вітчизняних фахівців щодо формування компетенцій бізнесу та компетенцій сучасної молоді, розбіжності та збіги. Перспективи подальших досліджень будуть направлені на дослідження понять бізнес-освіта та бізнес-компетенції, вивчення можливості впровадження програмних підходів бізнесосвіти при формуванні бізнес-компетенцій у випускників ВН3, як механізму поєднання потреб бізнесу з можливостями сучасних ВНЗ і як відгук на запит ринку праці.

\section{СПИСОК ВИКОРИСТАНИХ ДЖЕРЕЛ}

1. Закон України про освіту.[Електронний ресурс]. - Доступ до ресурсу/ https://zakon.rada.gov.ua/laws/show/2145-19 
2. Освіта 4.0: Головні освітні тренди майбутнього. [Електронний ресурс]. - Доступ до pecypcy/ https://osvitoria.media/experience/osvita-4-0-golovni-osvitni-trendy-majbutnogo/

3. «Оцінка економічного потенціалу університетів Донбасу: проблеми підготовки кадрів i безробіття» [Електронний ресурс]. - Доступ до ресурсу/

http://nvngu.in.ua/index.php/uk/vidavnitstvo/redaktsijna-kolegiya/1820-ukrcat/arkhivzhurnalu/2019

4. Проект Концепції розвитку освіти до 2025 року. [Електронний ресурс]. - Доступ до pecypcy/ https://osvita.ua/news/43501

5. Регулювання ринку праці в Україні та ЄС: спільні риси ц відмінності. Адаптація трудового законодавства України до законодавства СС. [Електронний ресурс]. - Доступ до pесурсу/_http://scc.org.ua/content/regulyuvannya-rinku-praci-v-ukrayini-ta-ies-spilni-risiy-vidminnosti-adaptaciya-trudovogo

6.Реформа ринку праці. [Електронний ресурс]. - Доступ до ресурсу/

http://www.me.gov.ua/Documents

7. Уиддет С. Холлифорд С. Руководство по компетенциям/ Пер. с англ., - М.: Издательство ГИПО, 2008. - 228 с.

8. Урідовий портал. [Електронний ресурс]. - Доступ до ресурсу/ https://www.kmu.gov.ua/news

9. Центр досліджень соціальних комунікацій НБУВ. [Електронний ресурс]. - Доступ до pecypcy: http://nbuviap.gov.ua

10. The 10 skills you need to thrive in the Fourth Industrial Revolution. [Електронний ресурс].

- Доступ до ресурсу:https://www.weforum.org/agenda/2016/01/the-10-skills-you-need-tothrive-in-the-fourth-industrial-revolution/. 